\title{
The Pedagogical Applications of Mobile-Assisted Language Learning (MALL) in Improving the Iranian EFL Learners' Oral Performance
}

\author{
Bahram Moghaddas $^{1,2}$, Hassan Bashirnezhad ${ }^{3}$ \\ ${ }^{1}$ Department of English, Khazar Institute of Higher Education, Mahmoodabad, Mazandaran, Iran \\ ${ }^{2}$ Mahmoodabad Educational Administration, Mahmoodabad, Mazandaran, Iran \\ ${ }^{3}$ Department of English, Farhangian University, Mazandaran Campus, Sari, Iran \\ Email address: \\ dr.moghaddas@khazar.ac.ir (B. Moghaddas), haba1350@gmail.com (H. Bashirnezhad)
}

\section{To cite this article:}

Bahram Moghaddas, Hassan Bashirnezhad. The Pedagogical Applications of Mobile-Assisted Language Learning (MALL) in Improving the Iranian EFL Learners' Oral Performance. International Journal of Applied Linguistics and Translation. Vol. 2, No. 1, 2016, pp. 8-14.

doi: $10.11648 /$ j.ijalt.20160201.12

\begin{abstract}
In the era of globalization, the use of mobile technologies changed the teaching-learning process in the various educational levels to make the pedagogy natural, vivid and interactive. Implementing global technologies in the educational contexts not only promote the level of teaching but also motivate the learners in providing information by means of innovative and attractive tasks. The appropriate use of mobile-related technologies in and outside classroom facilitates the teachinglearning process and helps the students learn the language better and gain information in depth. Language instructors can create the suitable environment for teaching by applying technology. The present article deals with the effective use of mobile-related technologies in the Iranian EFL contexts. The learners were divided into two groups of experimental and control, each group consisted of 30 students to assess the validity and utility of MALL in an English language institute. The results showed that the experimental group outperformed the control group and learners' fluency improved in their speaking skill.
\end{abstract}

Keywords: Mobile-Assisted Language Learning, Oral Performance, Language Learning,

Computer-Assisted Language Learning, Speaking Skill

\section{Introduction}

During the last century, education has been under gradual changes and evolution from being exclusively an agenda at the hands of elite to a widespread concept at the service of the public. Classroom education has been replaced by the virtual environments in the learning approach through technologies which enhance the communicative competence. Knowledge acquisition is no longer confined to the classroom. Hence, in a knowledge society everyone is searching to hunt for knowledge.

A knowledge society is a learning society which tries to provide opportunities for the people to seek for knowledge.

Therefore, technology aids to promote lifelong learning indirectly (Norazah Mohd Nordin et al., 2010). The application of technology in language learning has transited from desktop to palmtop devices such as mobiles and tablets, and thereby the concept of MALL has come into existence.

\section{Meaning and Nature of MALL}

MALL is a subcategory of both mobile learning (MLearning) and computer-assisted language learning (CALL). It is a two-way process which comprises the aid of handheld technology and any other similar portable devices to reduce inadequacy of learning location with the mobility of general portable devices. It also includes the use of mobile technologies such as cellphones, MP3 and MP4 players, notebooks, hand-held mini computers, cameras, data storage devices, PDAs and devices such as the iPhone or iPad.

Ally (2009) enumerates Mobile Learning as the delivery of learning content to mobile devices (Hwang \& Tsai, 2011; Shih, Chu, Hwang, \& Kinshuk, 2010). Hence, it is generally getting hold of any knowledge and skill by using mobile technology everywhere at any time to provide the different learning materials on hand. In fact, M-Learning not only brings strong portability by substituting books and notes with a mobile RAM packed with small modified attractive 
learning materials but also merges vivid games for a more appropriate and entertaining knowledge getting.

\subsection{Salient Features of Mobile Learning}

Technology is all-pervading, affecting almost every aspect of our daily life. Compare to desktop and laptop computers, the access to mobile network is of low cost and economically advantageous. Mobile learning is convenient from anyplace, provides access to the classroom activity contents and helps learners communicate with their teachers and peers at any time. As Sharples et al. (2005) states: "[it] is the learner that is mobile, rather than the technology" (p3).

Some of the salient features of Mobile Assisted Language Learning are as follows:

1. Mobility of learning setting

2. Interactivity of the learning process

3. Immediate and urgent need of learning

4. Integration of instructional content

5. Inventiveness of knowledge acquaintance

\subsection{Affordances and Constraints of MALL}

Boosting language learning through MALL affords some dynamics and imposes some constraints which are unique to m-learning compared to the traditional classroom or elearning. Failing to use the MALL technology will lead to widening the gap between educators' ideas about learning and those of their students. (Kukulska-Hulme \& Jones, 2011).

The most important affordance of a MALL technology is its ubiquitous access to learning anytime at any place. In a regular traditional classroom, the learners have to sit in a class or at a computer to access learning materials. They also afford new dynamics for collaborative learning as users can share the learning process in small synchronous groups (Nah, et al. 2008). They are relatively cheap technology, use cheap or nearly free content, and are learner driven and centered. Such portable technologies are still new and fashionable and go beyond the realm of the classroom and into the learner's environments and accordingly become more situated, personal, collaborative and lifelong (Naismith et al., 2004; Norazah Mohd Nordin et al., 2010; Ros i Solé, Calic, \& Neijmann, 2010). MALL encourages and facilitates peer interaction, integrates real life into learning, and are potential for learner autonomy.

Kloper et al. (2002) enumerates five properties of mobile devices which can generate ubiquitous pedagogical affordances:

- Portability-the small size and weight of mobile devices eases the relocation of these technologies within different sites.

- Social interactivity-mobile devices can help the face-toface data exchange and collaboration among the language learners.

- Connectivity-connecting mobile devices to data collection devices as well as the other devices create a shared network.

- Context sensitivity-the ability to gather and respond to the real or simulated data via the current location, environment and time.

- Individuality-the various tasks and activities can be customized for the individual learners.

Poor sound, download speeds, limited devices and display quality are the most notable constraints for MALL which have been reduced through the use of newer integrated PDA devices as they have narrowed the gap with higher access speeds, larger screens, having functions and capacities similar to laptop computers (Nah, et al. 2008). Other limitations of the mobile learning may be as follow:

- Teacher resistance

- Alignment of mobile learning with theoretical frameworks

- Technology-driven materials and practices

- Institutional rules

- Cultural appropriateness

- Cost

- Privacy

- Access to network

- Cross platform compatibility

\subsection{Challenges of Mobile Learning in EFL Classrooms}

Mobile Learning encounters various challenges for stakeholders and students regarding all the mobile devices as follow (Jacob \& Issac, 2008):

Adaptive Learning - This requires the adaptation of the educational strategies and learning content based on the learner's profile, personal needs and the learners' location.

Limited Text Display - It reflects the mobile devices support in revealing the various learning activities during the learning process.

Instant Communication - As response time and location are the crucial factors which facilitate the successful outcome in a trustful academic interaction and learner satisfaction, prompt notifications of message reception through the mobile communication network are essential.

\subsection{The Implication of MALL in the EFL/ESL Classrooms: Application and Interaction}

The changing world demands innovative pedagogical practices in higher education with an anchor to technology. The need to ICT equipped and smart classrooms (Yedla, 2013) compared to conventional classes aids the quality and effectiveness of the teaching-learning process and the access to reliable information anytime, anywhere. Hence, to achieve the goal, technology-related instructional and learning materials and activities should be adopted to the new generation learners.

In the EFL/ESL classrooms, MALL can be utilized by the teacher to booster the different techniques and strategies of learning. The following ways aid the process:

- Record the lecture and upload it as a podcast. Mobile devices, iPods and MP3 recorders are the tools which lessen the instructors and learners' worry about the insufficient hardware supply as they can record content 
for podcasts at any time (Facer and Abdous, 2011). As a result, the contents can be shared to the other learners' mobiles for studying or reference.

- Dedicate numbers to each learner and ask them to message their questions. The learners' questions reflects the salient features the teacher should focus on in the class and where to help and direct them.

- Ask a query relevant to the teaching materials and make the learners find the answer as quickly as possible. This shows how well the students noticed and understood the content as well as their attention and look to the materials.

- Make a list of important points to be shared through messaging. This will bridge the educational gap among the students.

- Let the students take a look at the content through the $3 \mathrm{G}$ webs in their mobiles. Then, ask them to put away their mobile phones and start testing their linguistic knowledge related to the PPP Approach (Yelda, 2012).

- Develop the students' vocabulary by sending flashcards through mobiles.

\section{Design of the Study}

The study aimed at the application of mobile phones in improving the speaking fluency of Iranian EFL learners in their classroom activities. The study is a new dimension compared to the previous studies as they mostly impacted on the other dimensions of language learning. As the lack of appropriate lexicon in the classroom conversations is a crucial factor in the speaking skill and causes learners to shy away from speaking and engaging in the classroom activities, the purpose of the study is to improve the fluency of students in their speaking skill.

The primary reason for this study was to utilize an innovative yet basic approach to enhance the oral proficiency of Iranian EFL learners. The main purpose of utilizing cell telephones was that occasionally as a result of lack of time in oral communicative activities, the learners' mistakes go by unnoticed and accordingly a few wrong structures will be fossilized in the learners' interlanguage system. The use of mobiles in the pedagogical and real contexts aids them to make our students analysts of their own developing linguistic system and increase their sense of autonomy. In addition, most Iranian EFL students have fluency problems when speaking which renders lack of or inadequate systematic instruction to have their mistakes corrected. Hence, the study was an attempt to foster and booster the fluency performance of the learners through a somewhat creative and orderly approach to help them conquer their speaking problems.

\section{Method}

\subsection{Participants}

The participants in this survey were 30 intermediate EFL students at Iranian Language Institute in Mazandaran, Iran. The purpose of the study was to reduce the learners' mistakes in their speaking skill during the class activities as it seemed that they had major problems in using correct forms and fluent English despite the exposure to the various patterns and activities in the pre-intermediate level. As the participants faced with little opportunity in correcting their wrong utterances, the researcher felt the need to design and use fluency-based techniques and activities to help them analyze their mistakes and as a result correct them. The researcher believed that using cell phones in the language environments provide the chance with the learners to correct themselves and assist them to overcome the various errors and thus become fluent learners of English.

\subsection{Instrument}

The first test was the Oxford Placement Test (OPT) which includes 100 items in multiple-choice format. It was used to homogenize the participants and to determine their language proficiency level. Then, as a pre-test, the teacher asked the learners to represent their lectures orally in the classroom based on the class course book speaking tasks. After ten sessions as the treatment period for the experimental group, a post-test was administered to all the learners and different descriptors for spoken fluency was measured.

\subsection{Procedure}

In order to answer the research questions, two groups, each consisting of 15 participants were involved in this study. An OPT was given to the learners to assess their proficiency level. Then all the participants try to present lectors in the class based on the required topics. Then, the results of the spoken fluency of the participants were computed based on the various measurement levels.

The first group was the experimental group, which received ten sessions of instruction on using mobiles as a tool to record the presentations in the classroom. Related topics based on the course book topics were selected as speaking tasks so that the learners could discuss lively and present in the lass. The students recorded their voices on the mobile phone during the class presentations. Then, they were asked to analyze their speeches and try to detect the errors and correct them the next session coming to the class. The teacher also required the students to play their voices to the other learners in the classroom for the identification of the unnoticed errors by the classmates. Moreover, they were asked to report on their errors in written form on separate sheets. The researcher then analyzed, corrected the error sheets, and gave back them later to the participants. The second group, the control group, received the conventional way of representing the speaking tasks in the class without using mobile phones. Finally, at the end of the treatment period, they were asked to discuss the topics in the class, their presentations were analyzed according to the measurement scales, and the results were compared to the pre-test. 


\subsection{Measurements}

In the current study, the speaking fluency of the learners were calculated according to the measures of utterance fluency. Utterance fluency is simply defined as measuring (temporal) aspects of the speech sample. Utterance fluency as Skehan (2003) and Tavakoli and Skehan (2005) remarks is a construct with several aspects including breakdown fluency, speed fluency, and repair fluency. Breakdown fluency considers the ongoing flow of speech and was measured by counting the number and length of filled ("uhms" and "uhs") and unfilled pauses in this study.

Speed fluency was measured by inverse articulation rate, that is, mean duration of syllables (speaking time divided by total number of syllables). Repair fluency was measured based on the number of corrections and number of repetitions. Thus, the following fluency measures were calculated based on the followings criteria: number of silent pauses per 100 words, mean duration of silent pauses (ms), number of filled pauses per 100 words, number of corrections per 100 words, number of repetitions per 100 words, and mean duration of syllables (ms). To measure utterance fluency, ten monologue speaking tasks were administered in the class and then the data were gathered and analyzed to evaluate the efficacy of mobile phones in Iranian EFL contexts.

\section{Results}

Table 1. Range of the fluency measures across tasks, Cronbach $\alpha$ between tasks, and mean (SD) over participants in pre-test in the experimental group.

\begin{tabular}{|c|c|c|c|}
\hline & Range & $\alpha$ & Mean $(S D)$ \\
\hline Fluency Variables & $(N=10)$ & $(N=15)$ & $(N=15)$ \\
\hline Number of silent pauses/100 words & $13.1-15.9$ & 0.97 & $14.5(5.3)$ \\
\hline Mean duration of silent pause (ms) & $135-163$ & 0.95 & $147(6)$ \\
\hline \multicolumn{4}{|l|}{ Number of } \\
\hline Filled pauses/100 words & $11.9-15.1$ & 0.94 & $13.5(6.3)$ \\
\hline Corrections/100 words & $6.1-7.8$ & 0.89 & $7.01(1.0)$ \\
\hline Repetitions/100 words & $3.7-5.6$ & 0.93 & $4.56(0.6)$ \\
\hline
\end{tabular}

Table 1 displays the descriptive statistics obtained in the pre-test for the experimental group. The results refers to the pre-test speaking tasks presented by the learners in the first session for all participants in the Group A.

The researcher measured the period between the cue and the end of the participants' response. A script written in PRAAT (Boersma \& Weenink, 2007) was applied to determine the latencies. The response times for all correct responses were measured. The incorrect responses and outliers were also replaced by missing values.

Table 2. Range of the fluency measures across tasks, Cronbach $\alpha$ between tasks, and mean (SD) over participants in pre-test in the control group.

\begin{tabular}{llll}
\hline & Range & $\boldsymbol{\alpha}$ & Mean (SD) \\
\hline Fluency Variables & $(N=10)$ & $(N=15)$ & $(N=15)$ \\
Number of silent pauses/100 words & $14.4-16.8$ & 0.98 & $15.6(5.7)$ \\
Mean duration of silent pause (ms) & $123-159$ & 0.96 & $145(7)$ \\
Number of & & & $14.15(7.1)$ \\
Filled pauses/100 words & $12.7-15.6$ & 0.97 & $7.05(1.0)$ \\
Corrections/100 words & $6.8-7.3$ & 0.85 & $4.85(0.9)$ \\
Repetitions/100 words & $3.8-5.9$ & 0.94 & $110(23)$ \\
Mean duration of syllable (ms) & $93-117$ & 0.95 & \\
\hline
\end{tabular}

Table 2 shows the descriptive statistics obtained in the pre-test for the control group. The results reveals the pre-test speaking tasks presented by the learners in the first session for all participants in the Group B. The measurement scales and process is the same as the first group, the experimental group.

Then, the students went through the treatment period for ten sessions and the results after the descriptive statistics were as follow:

Table 3. Range of the fluency measures across tasks, Cronbach $\alpha$ between tasks, and mean (SD) over participants in post-test in the experimental group.

\begin{tabular}{llll}
\hline & Range & $\boldsymbol{\alpha}$ & Mean (SD) \\
\hline Fluency Variables & $(N=10)$ & $(N=15)$ & $(N=15)$ \\
Number of silent pauses/100 words & $7.3-9.4$ & 0.98 & $8.4(3.2)$ \\
Mean duration of silent pause (ms) & $86-97$ & 0.96 & $91(3)$ \\
Number of & & & \\
Filled pauses/100 words & $5.1-7.6$ & 0.97 & $6.3(4.1)$ \\
Corrections/100 words & $2.1-3.4$ & 0.91 & $2.3(1.0)$ \\
Repetitions/100 words & $1.9-3.2$ & 0.95 & $2.6(0.5)$ \\
Mean duration of syllable $(\mathrm{ms})$ & $45-61$ & 0.98 & $52(11)$ \\
\hline
\end{tabular}


Table 3 reveals the results of the treatment in the experimental group after ten sessions. It shows that mobile phones can have valuable effects on the learning process of Iranian EFL learners at the intermediate level. After the period, the learners could enormously develop their fluency performance which is in line with De Jong et. al, (2012), Osborne (2007), and Warschauer (1996) studies regarding the effectiveness of mobile phones in the language classes.

Table 4. Range of the fluency measures across tasks, Cronbach $\alpha$ between tasks, and mean (SD) over participants in post-test in the control group.

\begin{tabular}{llll}
\hline & Range & $\boldsymbol{\alpha}$ & Mean $($ SD $)$ \\
\hline Fluency Variables & $(N=10)$ & $(N=15)$ & $(N=15)$ \\
Number of silent pauses/100 words & $13.7-15.9$ & 0.96 & $14.6(5.7)$ \\
Mean duration of silent pause (ms) & $128-146$ & 0.94 & $135(9)$ \\
Number of & & & \\
Filled pauses/100 words & $13.1-15.9$ & 0.97 & $13.95(6.3)$ \\
Corrections/100 words & $5.4-7.8$ & 0.88 & $7.01(1.0)$ \\
Repetitions/100 words & $4.1-6.7$ & 0.96 & $5.23(0.8)$ \\
Mean duration of syllable (ms) & $87-129$ & 0.98 & $108(21)$ \\
\hline
\end{tabular}

Table 4 displays the post-test results for the experimental group after ten sessions of regular teaching in the class. The teacher used a regular method during the teaching hours in which the students were asked to present their topics and cooperatively participate in the class discussions. The results for the two groups indicated that the mean score of the experimental group in disfluency is significantly lower than that of the control group which used the traditional method of presentations.

\section{Discussion}

The present study attempted to show the efficacy of using mobile phones for boosting the speaking fluency of a group of the intermediate Iranian EFL students. The results showed the effectiveness of applying mobile phones in promoting the speaking performance of the learners. The results of the study confirmed Sharples (2005), who asserted the importance of mobile phones in knowledge building. It also confirmed Nah, White, \& Sussex (2008) and Rosell-Aguilar (2007), who emphasized on the affordance of the utilization of mobile phones for language learning.

Alternatively, it declares that the use of mobile phones for language learning might facilitate the process of language learning while possible challenges can be accommodated or alleviated (Stockwell, 2008; Stockwell. 2012; Thornton \& Houser, 2005; Oberg \& Daniels (2013); Burston, 2013). Stockwell (2012) not only maintains the daily emergence of new technologies in educational environments but also enumerates the new types of practical constraints in their usage. Unavoidably, using technology in various teaching and learning contexts will lead the learners into being more motivated, imaginative and creative (Wong and Looi, 2010). As Kolb $(2008,2011)$ remarked mobile phones are the toys which can be converted to tools in learning with joy. The research rejects the findings of Salaberry (2001), who denied the effectiveness of mobile phones for language learning.

Hence, the results are in line with the concept of zone of proximal development (ZPD) by Vygotsky (Lantolf, 2000) which declares learning is the result of a joint social collaboration and cooperation between a more and a less knowledgeable person. Presenting a redefinition of ZPD and asserting the social nature of learning, Foley (1991) considers second language learning a self-regulating process which should be controlled by the teacher or the syllabus although the classroom and teacher environment are all mediators in L2 learning. Accepting the Clifton's ideas (2006) regarding the language learners' freedom in practical participation which makes them more initiative and responsible for learning, Reynolds (1990) sees the fulfillment of this goal through sharing discursive resources and letting the instructor's power go.

Hence, the adequate incorporation of technological innovations in language learning and the implementation of mobile phones strongly foster a high degree of control of the process by the learner, as well as improve communicative competences in an autonomous way (Seiz-Ortiz and RomeroForteza, 2013). Then, dedicating the responsibility of learning to learners can lead to better learning. Based on Swain's (1995) output hypothesis, noticing function as one of the functions of output helps learners notice gaps in their interlanguage as a result of synthetic processing when uttering L2 sentences than attending to output. So, extensive opportunities for producing output might results in the noticing of specific structures by the learners.

The pattern of the speaking tasks (preparation, practice, and evaluation) also assisted the tentative success of this research. Through the preparation stage, the teacher provides a context for speaking, then learners produce their target structures in a controlled and supportive manner in the practice stage, and finally in the evaluation stage, the learners are required to monitor and assess their own learning process through attending to the examined skill (Burns and Joyce, 1997; Carter and McCarthy, 1995).

\section{Conclusion}

Using mobile phones has made the language learning process very much easy and fast. The development of mobile technologies as the new frontiers for teaching and learning has generated a great amount of motivation and excitement among practitioners and academicians as it shifts the 
academic environment from traditional setting to innovative learning environments. Hence, this paper aimed at the efficacy of mobile phones in promoting the speaking fluency of Iranian intermediate EFL learners. The results revealed the outperformance of the experimental group comparing to the control group as the mean scores based on the different factors in assessing the students' fluency declared. The results asserted the impact of mobile phones in fostering the fluency performance of the learners in their speaking skill. The study was a new perspective at the dilemma of communicative oriented practitioners in promoting the speaking fluency of language learners. It provided a valuable and practical setting for those teachers in the developing countries like Iran who have no complete access to the sophisticated technologies in their classes

\section{References}

[1] Ally, M. (Ed.). (2009). Mobile learning. Transforming the delivery of education and training. Edmonton: AU Press.

[2] Boersma, P., \& Weenink, D. (2007). PRAAT. Retrieved from http://www.praat.org

[3] Burns, A. and Joyce, H. (1997). Focus on speaking. Sydney: National Center for English Language Teaching and Research.

[4] Bursten, J. (2013). Mobile-Assisted Language Learning: A Selected Annotated Bibliography of Implementation Studies 1994-2012. Language Learning \& Technology. Volume 17, $\begin{array}{llll}\text { Number } & 3 . & \text { pp. }\end{array}$ http://llt.msu.edu/issues/october2013/burston.pdf

[5] Carter, R and McCarthy, M. (1995). Grammar and Spoken Language. Applied Linguistics, Vol 16 No 2. 141-158.

[6] Clifton, J. (2006). Facilitator talk. ELT Journal, 60, 142-150.

[7] Foley, A. (1991). A psycholinguistic framework for taskbased approaches to language teaching. Applied Linguistics, $12,62-75$.

[8] Nah, Ki-Chune. White, Peter. and Sussex, Roland (2008). "The Potential of Using mobile Phone to Access the Internet for Learning EFL Listening Skills Within a Korean Context." ReCALL. $20 \quad$ (3): 331-347 http://www.eurocalllanguages.org/recall/index.html

[9] Klopfer, E, Squire, K and Jenkins, H. (2002). "Environmental Detectives: PDAs as a window into a virtual simulated world." Proceedings of IEEE International Workshop on Wireless and Mobile Technologies in Education. Vaxjo, Sweden: IEEE Computer Society, 95-98.

[10] Beethan, H., \& Sharpe, R. (Eds.). (2007). Rethinking pedagogy for a digital age: Designing and delivering elearning. London, UK: Routledge Falmer.

[11] Chinnery, G. (2006). Emerging technologies. Going to mall: mobile assisted language learning. Language Learning and Technology, 10 (1), 19-16.

[12] Colley, J., De Gani, A., \& Stead, G. (2010). What in the World are you doing with your mobile phone? World differences in the use of mobiles. Retrieved August 27, 2011, from http://www.mole-project.net/
[13] Colley, J., De Gani, A., \& Stead, G. (2010). Future trends in mobile use. Retrieved Aujust 27th, 2011, from http://www.mole-

project.net/images/documents/deliverables/global_mobile_tre nds.pdf

[14] Dias, A. Carvalho, L., Keegan, D. Kismihok, G., Mileva, N., Nix, J., \& Rekkedal. T (2008). An Introduction to Mobile Learning. Retrieved 25th July, 2011, from http://www.ericsson.com/ericsson/corpinfo/programs/the_role _of_mobile_learning_in_european_education/products/wp/soc rates_wp1_english.pdf

[15] De Jong, N. H., Steinel, M. P, Florijn, A., Schoonen, R. \& Hulstijn, J. H. (2012). Facets of speaking proficiency. Studies in Second Language Acquisition, 34 (1), (pp. 5-34) (30 p.).

[16] Facer, B. \& Abdous, M. (2011). Academic Podcasting and Mobile Assisted Language Learning: Applications and Outcomes. Hershey, PA: IGI Global.

[17] Geddes, S. (2004). Mobile learning in the 21st century: Benefit for learners. Knowledge Tree e-journal. Retrieved August 9th, 2011, from https://olt.qut.edu.au/udf/OLTCONFERENCEPAPERS/gen/st atic/papers/Cobcroft_OLT2006_paper.pdf.

[18] Hartman, G. De Gani, A., \& Stead, G. (2011). Cross-platform mobile development. Retrieved August 27th, 2011, from http://www.mole-

project.net/images/documents/deliverables/WP4_crossplatfor m_mobile_development_March2011.pdf

[19] Hwang, G.-J. \& Tsai, C.-C. (2011), Research trends in mobile and ubiquitous learning: a review of publications in selected journals from 2001 to 2010. British Journal of Educational Technology, 42: E65-E70. doi: 10.1111/j.14678535.2011.01183.x.

[20] Ismail, I., Baharum, H., \& Idrus, R. M. (2010). Simplistic is the ingredient for mobile learning. International Journal of Interactive Mobile Technologies, $4(3), 4-8)$ retrieved July 25th, 2011, from http://online-journals.org/i-jim/issue/view/85

[21] Jacob, S. and Issac, B. (2008) "The Mobile Devices and its Mobile Learning Usage Analysis", Proceedings of the International Multi-conference and Computer Scientists, pp 19-21.

[22] Kolb, L. (2008). Toys to Tools: Connecting Student Cell phone to Education in and out of the Classroom. USA: International Society for Technology in Education.

[23] Kolb, L. (2011). Adventures with cell phones. Educational Leadership, 68 (5), 39-43.

[24] Kukulska-Hulme, Agnes and Jones, Chris (2011). The next generation: design and the infrastructure for learning in a mobile and networked world. In: Olofsson, A. D. and Lindberg, J. Ola eds. Informed Design of Educational Technologies in Higher Education: Enhanced Learning and Teaching. Hershey, PA: Information Science Reference (an Imprint of IGI Global), pp. 57-78.

[25] Kukulska-Hulme. A., and Shield, Lesley (2008). An overview of mobile assisted language learning: From content delivery to supported collaboration and interaction. ReCALL, 20 (3), pp. 271-289.

[26] Kukulska-Hulme, A. (2006). Mobile language learning now and in the future. In: Svensson, Patrik ed. Fran vision till 
praktik: Sprakutbildning och Informationsteknik (From vision to practice: language learning and IT). Sweden: Swedish Net University (N"atuniversitetet), pp. 295-310.

[27] Lantolf, J. P. (2000). Introducing sociocultural theory. In J. P. Lantolf (Ed.), Sociocultural Theory and Second Language Learning (pp. 1-26). Oxford: Oxford University Press.

[28] Mirland, M. (2006). How should learning activities using mobile technologies be designed to support innovative educational practices, In M. Sharples (ed.) (2006) Big issues in mobile learning. Report of a workshop by the Kaleidoscope Network of Excellence Mobile Learning Initiative. University of Nottingham, UK. (p. 27-29) Retrieved July 9th, 2011, from $\mathrm{http}: / /$ mlearning.noe-

kaleidoscope.org/repository/BigIssues.pdf

[29] Nah, K., C., White, P, \& Sussex, R. (2008). \&e potential of using a mobile phone to access the Internet for learning EFL listening skills within a Korean context. ReCALL, 20 (3), $331-347$.

[30] Naismith, L., Lonsdale, P., Vavoula, G., \& Sharples, M. (2006). Futurelab 11: Literature review in mobile technologies and learning. University of Birmingham, UK. Retrieved Octobor 21, 2009, from www.futurelab.org.uk/research/lit_reviews.htm

[31] Naismith, L., Lonsdale, P., Vavoula, G. and Sharples, M. (2004) Literature Review in Mobile Technologies and Learning, Report 11 for Futurelab, Retrieved September 10, 2011, from http://www.futurelab.org.uk/sites/default/files/Mobile_Techno logies_and_Learning_review.pdf

[32] Norazah Mohd Nordin, Mohamed Amin Embi, Melor Md. Yunus (2010). Mobile learning framework for lifelong learning. International Conference on Learner Diversity 2010. Procedia Social and Behavioral Sciences 7 (C), 130-138.

[33] Oberg, A., \& Daniels, P. (2013). Analysis of the effect a student-centred mobile learning instructional method has on language acquisition. Computer Assisted Language Learning, 26 (2), 177-196.

[34] Osborne, J. 2007. Investigating L2 fluency through oral learner corpora. In Spoken Corpora in Applied Linguistics, M. C. Campoy \& M.J. Luzón (eds.). Frankfurt: Peter Lang, 181197.

[35] Reynolds, M. (1990). Classroom power: some dynamics of classroom task. In R. Clark, N. Fairclough, R. Ivanic, N. McLeod, J. Thomas, and P. Meara (Eds.), Language and power (pp. 122-136). Clevedon, Avon: BAAL and CILT.

[36] Rosell-Aguilar, F. (2007). Top of the pods - In search of a podcasting "podagogy" for language learning. Computer Assisted Language Learning, 20 (5), 471-492.

[37] Ros i Solé, C., Calic, J., \& Neijmann, D. (2010). A social and self-reflective approach to MALL. RECALL Journal, 22 (1), 3952. Retrievable from http://journals.cambridge.org
[38] Seiz-Ortiz, R., \& Romero-Forteza, F. (2013). Pedagogical evaluation of web-based autonomous language learning. Glasgow, 10-13 July 2013 Papers, 302.

[39] Sharples, M., Taylor, J., \& Vavoula, G. (2005). Towards a theory of mobile learning. Proceedings of mLearn 2005, 1 (1), $1-9$.

[40] Sharples, M. (2005) Learning as conversation: Transforming education in the mobile age, Proceedings of Seeing, Understanding, Learning in the Mobile Age, pp. 147-152.

[41] Stockwell, G. (2008). Investigating learner preparedness for and usage patterns of mobile learning. ReCALL, 20, 253-170.

[42] Stockwell, G. (2012). Commentary: Working with constraints in mobile learning - A response to Ballance. Language Learning \& Technology, 16 (3), 24-31.

[43] Salaberry, M. R. (2001). The use of technology for second language learning and teaching: A retrospective. Modern Language Journal, 85, 39-56.

[44] Swain, M. (1995). Three functions of output in second language learning. In G. Cook and B. Seidlhofer (Eds.), Principle and practice in applied linguistics: Studies in honor of H. G Widdowson (125-144). Oxford: Oxford University Press.

[45] Shih, J. L., Chuang, C. W. \& Hwang, G. J. (2010). An inquiry based mobile learning approach to enhancing social science learning effectiveness. Educational Technology \& Society, 13, $4,50-62$.

[46] Skehan, P. (2003). Task-based instruction. Language Teaching, 36, 1-14.

[47] Tavakoli, P., \& Skehan, P. (2005). Strategic planning, task structure, and performance testing. In R. Ellis (Ed.), Planning and task performance in a second language (pp. 239-276). Amsterdam: John Benjamins.

[48] Thornton, P., \& Houser, C. (2005). Using mobile phones in English education in Japan. Journal of Computer Assisted Learning, 21, 217-228.

[49] Wong, L. H., \& Looi, C. K. (2010). Vocabulary Learning by Mobile-Assisted Authentic Content Creation and Social Meaning-making: Two Case Studies, Journal of Computed and Assisted Learning, 26 (5), 421-433.

[50] Yedla, Suneetha, 2013. "Classroom to Smart Room: Need of the Hour for English for Engineering" Contemporary Research in India: An International Peer Reviewed Journal, Vol. 3, Issue 1, Pg: 115-117. ISSN: 2231-2137.

[51] Yedla, Suneetha, 2012. "Teaching Techniques in ESP for Technocrats", Thematics Journal of English Language Teaching: An International Peer Re viewed Journal, Vol. 2, Issue 1, Pg. No. 50-54, ISSN 2231-4873.

[52] Warschauer, M. (1996). Computer-assisted language learning: An introduction. In S. Fotos (Ed.), Multimedia language teaching (pp. 3-20). Logos International: Tokyo. 